Capillary Tube Technique

For Serologic Screening

Of Syphilis

By CHARLES R. FREEBLE, JR., M.D., M.P.H., and BERTTINA ORSBURN, B.S.

$\mathrm{T}$ HE NEED for a simplified method of obtaining blood specimens has been indicated by field observations in the venereal disease control program of the Ohio Department of Health. Obtaining blood by venipuncture is difficult on infants and small children, is objectionable to many adults, and is not suitable for use in the home. For these reasons we have been searching for a method of collecting capillary blood which would give laboratory results of significance.

A number of methods for the collection of small amounts of blood have been tried in the past, especially in pediatric work. The capillary tube collection method as reported in this paper was described by Davies (1) in 1938, and has been in use for several years in various pediatric hospitals, including Children's Hospital in Columbus, Ohio. It is surprising to us that this technique has not been applied more widely to public health work as it appears to have advantages over venipuncture for mass studies as well as for work with infants and children.

\section{Method of Collection}

The tubes used for collection of blood are cut in 8-cm. lengths from strong-walled glass tubing of approximately 2-mm. inside diameter, 4-mm. outside diameter, and 1-mm. wall thickness. These $8-\mathrm{cm}$. tubes hold approximately $0.4 \mathrm{ml}$. and can readily be filled two-thirds or three-fourths full by capillary action with blood from finger puncture, or from heel punc-

Dr. Freeble was formerly chief of the communicable disease division, Ohio Department of Health, Columbus, Ohio. Mrs. Orsburn is a medical technician with that division. ture on infants. The ends of the tubes are capped with No. 3-68 M. S. rubber vial stoppers which fit snugly on this diameter tubing, seal the tube well, and protect it from breakage if dropped. This length tube fits an ordinary mailing container and can be safely transported to the laboratory in a routine way.

The finger or heel is cleaned with alcohol, wiped dry, and a fairly deep stab made with a Bard-Parker No. 11 blade mounted in a cork. The capillary tube is filled with blood as described by Davies (2), holding the tube horizontally or tipped slightly downward, and allowing the blood to run into the tube by capillary action. It is not difficult to obtain the necessary amount of blood if the finger is wiped completely dry at the beginning, gentle pressure applied to allow the blood to well out in large drops, and the end of the tube touched to the drop of blood. The tube should not be held against the skin of the finger as this tends to let the blood run down the finger. When filled, the tube is capped at both ends with the vial stoppers. The tubes are numbered with 1-inch Scotch "Wetordry" masking tape No. 202 stamped with a Bates numbering machine. This tape does not loosen or come off in the water bath nor do the stamped numbers, when once dried on the tape, run or fade in the water.

\section{Method of Testing}

Before the tubes are placed in the centrifuge, blood clots are loosened with a strong wire 6 to 7 inches in length, and the tubes are then centrifuged at 2,000 rpm for 10 minutes. Following centrifugation, the entire specimen is inactivated in a water bath at $60^{\circ}-62^{\circ} \mathrm{C}$. for $3 \mathrm{~min}$ utes. It is not necessary to separate the serum from the clot for inactivation, and handling the blood in this manner conserves the serum and saves time in operation. The tubes are divided into lots of 10 in 250-cc. beakers, and the beakers are filled with water from the water bath to a level which covers the serums. The beakers are then placed in the water bath for inactivation. If the vial stoppers on the ends of the tubes are sufficiently tight no water enters even if the water level in the beaker is above the tops of the tubes.

When removed from the water bath, the tubes 
Table 1. Comparison of results of capillary VDRL test with Kahn, Kline, and Kolmer tests

\begin{tabular}{|c|c|c|c|c|c|c|}
\hline \multirow[t]{2}{*}{ Capillary VDRI } & \multicolumn{2}{|c|}{ Positive and doubtful } & \multicolumn{2}{|c|}{ Negative } & $\underset{\text { (percent) }}{\text { Agreement }}$ & $\begin{array}{l}\text { Disagree- } \\
\text { ment } \\
\text { (percent) }\end{array}$ \\
\hline & \multicolumn{6}{|c|}{ Kahn } \\
\hline \multirow[t]{2}{*}{$\begin{array}{l}\text { Positive and weakly positive } \\
\text { Negative }\end{array}$} & $\begin{array}{r}\text { Number } \\
403 \\
8\end{array}$ & $\begin{array}{r}\text { Percent } \\
64.7 \\
1.3\end{array}$ & $\begin{array}{r}\text { Number } \\
98 \\
113\end{array}$ & $\begin{array}{r}\text { Percent } \\
15.8 \\
18.2\end{array}$ & 82.9 & 17. 1 \\
\hline & \multicolumn{6}{|c|}{ Kolmer } \\
\hline \multirow[t]{2}{*}{$\begin{array}{l}\text { Positive and weakly positive } \\
\text { Negative }\end{array}$} & $\begin{array}{r}469 \\
24\end{array}$ & $\begin{array}{r}75.4 \\
3.9\end{array}$ & $\begin{array}{l}33 \\
96\end{array}$ & $\begin{array}{r}5.3 \\
15.4\end{array}$ & 90.8 & 9.2 \\
\hline & \multicolumn{6}{|c|}{ Kline } \\
\hline $\begin{array}{l}\text { Positive and weakly positive } \\
\text { Negative }\end{array}$ & $\begin{array}{r}494 \\
30\end{array}$ & $\begin{array}{r}79.5 \\
4.8\end{array}$ & $\begin{array}{r}7 \\
91\end{array}$ & $\begin{array}{r}1.1 \\
14.6\end{array}$ & 94.1 & 5. 9 \\
\hline
\end{tabular}

are set out in drilled wooden racks. Divided racks with separated shelves do not work well with these capillary tubes, as the flanges on the vial stoppers tend to catch and pull off when the tubes are put in and taken out of the rack.

Sixteen-gauge glass capillary tubing (approximately 2 -mm. outside diameter) in 6-inch lengths, holding $0.2 \mathrm{ml}$. serum, is used to remove the serum from the collecting tube. With a red wax pencil, a mark is placed 1.5 inches from the end of the tube to measure $0.05 \mathrm{ml}$. serum for the VDRL test. Some workers consider this length tubing difficult to handle. A shorter length, such as 3 inches, may be used. Sixteen-gauge tubing fits snugly into the smaller opening of a vaccine bulb (for example, bulbs used with smallpox vaccine sets). Using a vaccine bulb, a suction apparatus may be improvised to aid in withdrawing serum from the collection tube. The large opening in the vaccine bulb snugly fits the end of a small glass adapter (7-mm. outside diameter). Attaching a rubber dropper top from an ordinary typing serum bottle to the other end of the adapter completes the apparatus. Other workers have nicknamed this set-up a "squee-gee." With a squee-gee and marked tubing, $0.05 \mathrm{ml}$. of serum is removed from each sample and placed in a depression of a Boerner micro slide or paraffin ring slide (3).
The antigen is prepared and used as in the standard VDRL technique (4), one drop of antigen from a tuberculin syringe with a 22 -gauge needle $(1 / 60 \mathrm{ml}$.) being added to each serum sample. The plates are then rotated for 4 minutes at $180 \mathrm{rpm}$ on the Boerner rotator. Tests are read as positive, weakly positive, or negative as described in the VDRL technique.

\section{Results}

Venous and finger puncture blood specimens were collected simultaneously from 622 patients and employees of the Central Ohio Rapid Treatment Center. Standard Kahn, Kline, Kolmer, and quantitative Kahn tests were done by the laboratory of the Ohio Department of Health on the venous bloods. Capillary VDRL tests on the finger specimens were done at the rapid treatment center.

Of the 622 bloods tested, 397 (63.8 percent) gave positive results with all methods used, 91 (14.6 percent) gave negative results, and 134 (21.6 percent) showed varying disagreement. Table 1 compares the results of the capillary VDRL test with the results obtained from the Kahn, Kline, and Kolmer tests. Best agreement was obtained with the Kline tests.

Complete disagreement occurred in results of tests on 134 serums: The capillary VDRL test 
Table 2. Diagnostic status of individuals tested by the capillary VDRL tests and by other methods

\begin{tabular}{|c|c|c|c|}
\hline \multicolumn{2}{|l|}{$\begin{array}{c}\text { Capillary VDRL negative } \\
\text { Kline, Kolmer, Kahn, positive }\end{array}$} & \multicolumn{2}{|l|}{$\begin{array}{c}\text { Capillary VDRI, positive } \\
\text { Kline, Kolmer, Kahn, negative }\end{array}$} \\
\hline Diagnosis & $\begin{array}{c}\text { Number of } \\
\text { cases }\end{array}$ & Diagnosis & $\begin{array}{l}\text { Number of } \\
\text { cases }\end{array}$ \\
\hline $\begin{array}{l}\text { Early latent, with treatment } \\
\text { Late latent, } \\
\text { Late latent, with treatment } \\
\text { No venereal disease }\end{array}$ & $\begin{array}{l}2 \\
1 \\
3 \\
1\end{array}$ & $\begin{array}{l}\text { Primary, darkfield positive } \\
\text { Early latent, with treatment } \\
\text { Late latent, with treatment } \\
\text { Chancroid. }\end{array}$ & $\begin{array}{l}2 \\
1 \\
2 \\
1\end{array}$ \\
\hline 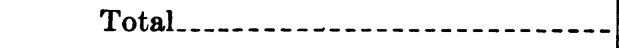 & 7 & Total & 6 \\
\hline
\end{tabular}

and the other three tests in 13 ; the Kline in 7 ; the Kolmer in 6 ; and the Kahn in 72 . On 36 of the 134 specimens, two of the tests were positive and two were negative. Table 2 presents the diagnostic classification of the 13 individuals whose serums when tested by the capillary VDRL were in total disagreement with the other tests.

Five hundred and forty-three (87.3 percent) of the 622 individuals tested were diagnosed syphilitic and 79 (12.7 percent) nonsyphilitic. The capillary VDRL was positive in 499 (91.9 percent) of the 543 diagnosed cases and negative in 77 ( 97.5 percent) of the 79 nonsyphilitics. Of the 44 syphilitics whose blood was negative to capillary VDRL, 32 were previously treated patients; 9 had primary syphilis; 2 late latent, and 1 central nervous system involvement.

Results of the various tests on the 622 patients and personnel at the Central Ohio Rapid Treatment Center, by syphilitic status, are presented in table 3.
Serums of three individuals among those diagnosed as nonsyphilitic gave positive tests. Two of these had diagnoses of apparent false positive serologic reactions due to recent immunizations. The third had chancroid, with a further diagnosis of possible primary syphilis, the final diagnosis depending upon further study.

Primary syphilis was the diagnosis in 32 individuals in the series. Of these, 12 were positive and 13 were negative to all tests. Of the seven remaining, six were positive to the capillary VDRL test. Table 4 presents the results of the four test methods on the seven patients having primary syphilis, when test results did not agree completely.

From these results, it appeared that capillary blood collected and tested in the manner described gave results which compared favorably with the results of standard serologic tests on venous blood.

There remained the problems of investigating the suitability of the collection method for mass

Table 3. Comparative results of battery tests, by syphilis status

\begin{tabular}{|c|c|c|c|c|c|c|c|c|c|c|c|c|c|c|c|c|}
\hline \multirow{3}{*}{ Result of test } & \multicolumn{8}{|c|}{543 diagnosed syphilis } & \multicolumn{8}{|c|}{79 diagnosed not syphilis } \\
\hline & \multicolumn{2}{|c|}{ Capillary } & \multicolumn{2}{|c|}{ Kahn } & \multicolumn{2}{|c|}{ Kline } & \multicolumn{2}{|c|}{ Kolmer } & \multicolumn{2}{|c|}{$\underset{\text { VDRL }}{\text { Capillary }}$} & \multicolumn{2}{|c|}{ Kahn } & \multicolumn{2}{|c|}{ Kline } & \multicolumn{2}{|c|}{ Kolmer } \\
\hline & 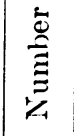 & 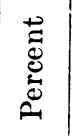 & 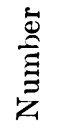 & 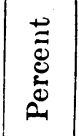 & $\frac{\mathfrak{D}}{\overparen{D}}$ & 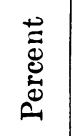 & $\frac{\dot{D}}{\frac{0}{\Xi}}$ & 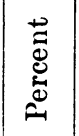 & 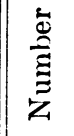 & 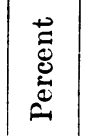 & $\underset{\grave{\Xi}}{\stackrel{\grave{\Xi}}{\Xi}}$ & 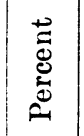 & $\frac{\grave{\Phi}}{\grave{\Xi}}$ & 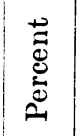 & 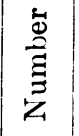 & 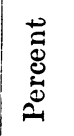 \\
\hline $\begin{array}{l}\text { Positive and weakly positive } \\
\text { Positive and doubtful } \\
\text { Negative. }\end{array}$ & $\begin{array}{r}499 \\
--- \\
44\end{array}$ & $\begin{array}{c}91.9 \\
-8.1\end{array}$ & $\begin{array}{l}409 \\
134\end{array}$ & $\begin{array}{l}75.3 \\
24.7\end{array}$ & $\begin{array}{r}523 \\
20\end{array}$ & 96. 3 & $\begin{array}{r}490 \\
53\end{array}$ & $\begin{array}{r}90.2 \\
9.8\end{array}$ & $\begin{array}{r}2 \\
\overline{77}\end{array}$ & $\begin{array}{r}2.5 \\
-97.5\end{array}$ & $7 \frac{2}{77}$ & $\begin{array}{r}2.5 \\
97.5\end{array}$ & $\begin{array}{r}2 \\
77\end{array}$ & $\begin{array}{r}2.5 \\
97.5\end{array}$ & $\begin{array}{r}1 \\
78\end{array}$ & $\begin{array}{l}1.3 \\
98.7\end{array}$ \\
\hline
\end{tabular}


Table 4. Comparative results of battery tests on 7 patients with primary syphilis

\begin{tabular}{|c|c|c|c|}
\hline Capillary VDRL & Kahn & Kline & Kolmer \\
\hline $\begin{array}{l}\text { Weakly positive } \\
\text { Positive }\end{array}$ & Negative & \multirow{5}{*}{ 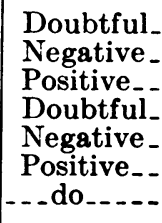 } & \multirow{5}{*}{$\begin{array}{c}\text { Negative. } \\
\text { Do. } \\
\text { Do. } \\
\text { Do. } \\
\text { Do. } \\
\text { Positive. } \\
\text { Do. }\end{array}$} \\
\hline Do & Positive & & \\
\hline Negative & Negative & & \\
\hline $\begin{array}{l}\text { Weakly positive } \\
\text { Positive }\end{array}$ & . do do..... & & \\
\hline Do & . do & & \\
\hline
\end{tabular}

testing and of determining the time necessary for a person untrained in this technique to develop proficiency in securing specimens.

By arrangement with the Zanesville City Health Department, Zanesville, Ohio, the collection technique was used in a mass survey conducted by that department among students of the two local high schools as a part of their health course. A team consisting of the junior author, two physicians, and two nurses who had never before used the method secured blood specimens from 1,106 students. The inexperienced collectors developed proficiency after collecting approximately 25 specimens and only 3 of the 1,106 specimens were later found unsatisfactory for testing. Six positive and weakly positive results were obtained, and follow-up observations disclosed three previously undiagnosed, untreated students with congenital syphilis, one who had been previously diagnosed and treated, and two with seemingly false positive reactions, who are still under study. Following this, 94 children in a Columbus Children's Home were tested. Their ages ranged from 4 to 12 years, and all tests were negative.

Somewhat more time was required to obtain specimens by capillary tube than by venipuncture, but when the time consumed in preparing and sterilizing venipuncture equipment was considered, the time differential disappeared.

\section{Discussion}

The method of collecting capillary blood specimens described here, which is essentially the same as that reported by Davies in 1938 (1), may be useful in a venereal disease control program. Using the VDRL test, significant results were obtained on 622 specimens when evaluated according to the stage of syphilis in the persons tested. Field experience in which 1,106 specimens were collected demonstrated the technique to be efficient and economical. Experience with 94 children has demonstrated the advantages of this technique over venipuncture.

\section{Summary}

1. A method for collecting capillary blood and testing for syphilis has been discussed. The method combines the advantages of collection by finger puncture and adequate laboratory results.

2. It is suggested that the method can become a useful tool in venereal disease control programs, particularly in regard to the screening of infants and children.

\section{REFERENCES}

(1) Davies, John A. V.: A method of collecting small blood specimens. J. Lab. \& Clin. Med. 23: 1206-1209 (1938).

(2) Davies, John A. V.: A microflocculation test for syphilis. J. Ven. Dis. Inform. 18: 1 (193i).

(3) Kolmer, John A., Spaulling, Earle H., and Robinson, Howard W.: Approved laboratory technic. Ed. 2. New York, N. Y., Appleton-Century-Crofts, 1951, p. 856.

(4) U. S. Public Health Service: Manual of serologic tests for syphilis. Supplement No. 22 to J. Ven. Dis. Inform., 1949, pp. 34-36.

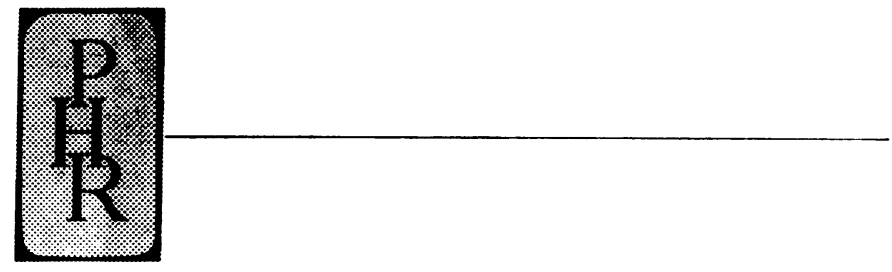

